\title{
THE EFFECT OF PAIR AND GROUP WORK IN COLLABORATIVE PRE- WRITING DISCUSSION ON STUDENTS’ WRITING QUALITY
}

\author{
Winarti \\ (winarti.wa@gmail.com) \\ Universitas Negeri Malang
}

\begin{tabular}{|c|c|}
\hline ARTICLE & ABSTRACT \\
\hline $\begin{array}{l}\text { Keywords: } \\
\text { Collaborative } \\
\text { learning, } \\
\text { pre-writing, } \\
\text { pair work, } \\
\text { group work }\end{array}$ & $\begin{array}{l}\text { In foreign language writing classroom, collaborative pre-writing activity is one } \\
\text { of common activities used by students to help them generate and evaluate their } \\
\text { ideas before they write a text. A teacher usually assigns students to work in } \\
\text { pairs or groups to accomplish the activity. However, whether the number of } \\
\text { participants in collaborative pre-writing activity influenced the quality of } \\
\text { students' writing or not is still mysterious that need to be investigated further. } \\
\text { This study tried to investigate the effect of the number of participants in } \\
\text { collaborative pre-writing discussion on students writing quality. } 30 \\
\text { participants from non-English department who were studying English as } \\
\text { English Specific Purposes were involved in this study. They were required to } \\
\text { write an explanation paragraph after being given a certain treatment. The result } \\
\text { of the study revealed that the quality of students' writing was not affected by } \\
\text { the number of participants in collaborative pre-writing discussion. Therefore, } \\
\text { the implication of the study is teacher can assign students to work } \\
\text { collaboratively in pre-writing activity with two or more students. However, } \\
\text { some factors need to be considered by teacher such as students learning style, } \\
\text { the nature of task, etc. }\end{array}$ \\
\hline
\end{tabular}

\section{INTRODUCTION}

Among the four language skills which should be mastered by L2 students, writing as a productive skill has been believed to be the most difficult skill for students including Indonesian students (Richards \& Renandya, 2002, Mukminatien, 1997; Widiati \& Cahyono, 2006). Some interactive and recursive processes involving during writing production make it an arduous task for students. Those processes include generating ideas based on a certain topic, organizing and linking them into a good order, supporting the idea with related details and examples, and choosing linguistic system and appropriate lexical items to translate those ideas into writing. According to Kellogg's (1996) model, in the process of accomplishment of a writing task students have to 
experience three substantial processes, namely formulation, execution, and monitoring. Formulation demands students to plan the content of the writing which involves generating the ideas and organizing those ideas into a good organization, and then selecting proper vocabulary and sentence structure needed. The second process is execution in which students write the text on a piece of paper or type it using electronic devices. The last, monitoring ensures that the content and language use are adequately conveyed students' ideas and if mismatches are apparent between what are to be written and what are already written, the created text is revised and rewrote. Thus, since students need to give attention on content and linguistic form during task production, teaching writing needs appropriate strategies to help students compose a piece of written product.

Since writing is a tedious task, some task based activities are created to help students improve their writing ability and one of which is pre-writing activity. It has been hypothesized that pre-writing as planning activity may contribute the improvement of the quality of writing. Information processing theory as theoretical rational also supports the implementation of prewriting activity which postulates that students' working memory is limited. It means that when students try to focus on content, the attention may be distracted by form focus attention as they may not be able to give full attention to both content and language form at the same time. As the result, giving a task activity in planning stage may lessen the load of student working memory during the task production.

When students are engaged in pre-writing activity, they get some benefits to improve their writing product. Seow (2002) stated that Pre-writing is any writing activity prior to drafting activity conducted in the classroom whose aim is to help students prevent from blank ideas since it encourages students to activate thought for generating ideas for the writing. Generally, students often have no idea what they want to write about, however, by having pre-writing activity students are encouraged to stimulate their thought to generate ideas for their writing. According to Kucer (2009), pre-writing activity is a prominent activity and has a great effect on the quality of content and language use since it gives more opportunities for students to think over not only the ideas but also the language used to convey the students' intention. The plans will direct and guide students from what they have already planned in pre-writing activity to what they desire to be when the text is completed. These benefits are in line with research findings on the positive effect of pre-writing on students' writing quality (Servati, 2012; Rao, 2007; Al-Shaer, 2014).

Amount of research has been devoted recently to investigate the effect of planning tasks on 


\section{JEASP}

Journal of English for Academic and Specific Purposes

Volume 2 Number 2, December, 2019

written production seen from writing aspects such as fluency, complexity and accuracy, however, but no conclusive findings could be found. A study conducted by Johnson et.al. (2012) showed that pre writing activity gave an insignificant effect on writing fluency, and the complexity of word choices and sentence structure were not influenced by pre writing condition. Similar finding from Ong \& Zhang's study( 2010) which attempted to investigate the effect of planning time given to 108 EFL students prior to actual writing activity on the quality of argumentative essay seen from fluency and lexical complexity. However, the result of Ellis and Yuan's study (2004) revealed a different finding in which pre-task planning contributed significantly to writing fluency and grammatical complexity. The different findings in these studies may have been influenced by students' educational experience, educational background, and knowledge of text types.

Regarding to prewriting strategy, prewriting can take on many different forms. It can be in the form of a concept mapping (Al-Shaer, 2014), a graphic organizer (Servati, 2012), a brainstorming (Rao, 2007), collaborative discussion (Neumann \& McDonough, 2015). Prewriting can also be done either individually or collaboratively in which it can allow students to work with partners or within groups. Among different kind of strategies in pre-writing, collaborative prewriting has been considered as an influential role in the second/foreign language classroom, given that collaborative activities involving two or more students promote mutual interaction and support communicative language teaching. To date, the small number of research on collaborative prewriting activities has been directed to examine the effectiveness of collaborative pre-writing activity on students' composition quality. Lee (2013) reported in his study that providing students with activity to map their ideas gave a positive impact on improving the quality of writing. However, she did not find a positive evidence of collaborative concept mapping activity on the improvement in writing score except for better performance on generating idea compared to individual working. Shi (1998) examined the effect of three types of pre-writing activities teacher-student discussion, student-student discussion, individual work-on students' composition and it was found that the three pre writing conditions resulted no different quality of students' composition, however, the drafts composed by students who were given an opportunity to discuss with their friends led to better draft in term of having more various verb which indicated mental process compared to drafts produced by students who worked individually. No significantly effect of pre-writing condition on students' composition might be caused by the use of unstructured group planning activities during pre-writing task. Unstructured discussion led students to generate unordered ideas which came out erratically and challenged students to order and organize those 


\section{JEASP}

Journal of English for Academic and Specific Purposes

Volume 2 Number 2, December, 2019

ideas before writing. To fulfill the gap from Shi's study, Neumann and McDonough (2015) conducted similar study which addressed the question whether the quality of written text was affected by structured collaborative prewriting task. The findings indicated that students' talk which elicit the occurrence of content and organization episodes appeared while students were talking about the given topic in structured collaborative prewriting tasks, but there was only a moderate relationship between these prewriting discussions and the students' written texts. From these two studies, the researchers did not specify the number of participant in their study. They just indicated their participant as collaborative group which consisted of more than 1 student.

Meanwhile, study on specifically comparing the effectiveness of assigning students in pair and group work in second or foreign language is still scarce. A study was conducted by Losito and Storch (2013) inform us about whether there were more benefits assigning students in pairs over group work during collaborative learning. The result of their study indicated that students working in pairs produced more language related episodes (LREs) than small groups. Swain and Lapkin (1998) stated that "LRE is any part of a dialogue where language learners 'talk about the language they are producing, question their language use, or correct themselves or others". However, when working in small groups students had a tendency to speak the target language and were able to solve language related problems correctly. Dobao's (2014) study showed a contrasting result. The study found that LREs produced during group interaction were greater and resolved correctly than that of pair work. The researcher concluded that small groups might provide better condition to execute collaborative learning as it had more students who could generate more language and knowledge to be used in a certain task and as the result the language related problems produced by group work tended to be resolved correctly. Another study on the effect of group size on the quality of writing composition on the aspect of the fluency, complexity, and accuracy was examined by Dobao (2012). The investigation revealed that the groups were able to compose the text more accurately than pairs. In conclusion, previous studies on the effect of the number of participants in collaborative activities have not obtained conclusive result on the most effective number in collaborative activity, so it is necessary to investigate this issue to obtain clear understanding on the role of number of participants in collaborative pre-writing activity.

Furthermore, students' perception of working in pair or group work has been examined by some researchers. Peacock (1999) investigated students' perception by addressing three research questions on the level of difficulty working in pairs or groups; students' preference working in 


\section{JEASP}

Journal of English for Academic and Specific Purposes

Volume 2 Number 2, December, 2019

pairs or groups; and the benefit students gain from pairs or groups. The data revealed that working in pairs was significantly harder than that of pairs; more than $50 \%(59 \%)$ students preferred working in group work, and the remaining percentage liked to work in pairs. For question three, it was suggested that there was a link between levels of on-task behavior and linguistic progress. In addition, Dobao and Blum (2013) found that the students preferred pair work as they got more opportunities to be active during a task completion. Meanwhile, those who preferred in groups thought that working in groups gave them more ideas and knowledge to share since there were more students involving in the task, and therefore more possibilities for language development.

In conclusion, teachers often apply collaborative writing by assigning students to work together either in pairs or small groups since the strategy promotes sharing knowledge which may give a positive effect on the quality of produced text. The use of pair and group work gains a support from various theoretical approaches. However, studies which devoted to examine specifically the impact of group size in collaborative pre writing activity is so scarce to date. Therefore, the present study set out to investigate the issue on how the number of participants in the task may affect the quality of students writing. It compared groups of four learners and dyads as they performed collaborative pre writing discussion then it analysed the text produced by students to find out the best group size in collaborative writing. Therefore, the study intended to answer the following question.

"Does the number of participants in collaborative pre writing discussion affect the quality of the written texts produced?"

\section{METHOD}

This study was set out to investigate the effect of different number of participants in collaborative pre-writing discussion to the quality of written produced by students. Counterbalance design was employed involving an intact class group, rotated the groups at intervals during the experimentation. The intact class was divided into two groups in which half of students worked in pairs (treatment A) and another half worked in group (treatment B). The next meeting, the half students who had worked in pair exchanged the treatment to work in the group. All students received all experimental treatments but in a different order. Thus, this design use counterbalanced design which consists of a series of replications; in each replication, the groups were shifted so that at the end of the experiment each group had been exposed to each treatment. 


\section{JEASP}

Journal of English for Academic and Specific Purposes

Volume 2 Number 2, December, 2019

Thirty non-English Department students volunteered to participate in this study. They were from Mathematics Department at Universitas Islam Negeri Maulana Malik Ibrahim Malang who was taking English 2 which focused on the mastery of reading and writing skill after they finished successful previous English course (English 1). Twenty-five were female and five was male, and their ages ranged from 19 to 20, with an average of 19. They were all students for whom English was a foreign language, and they were all categorized into intermediate level language learners as stated in their achievement score in Test of English Proficiency (TEP) conducted by English Language Center at Universitas Islam Negeri Maulana Malik Ibrahim Malang.

There were three instruments used in this study which were collaborative pre-writing discussion worksheet, writing test, and scoring rubric. The worksheet was used to guide the participants in doing collaborative pre-writing discussion and it was adapted from Neumann \& McDonough (2015). The worksheet contained three sections: (a) a section presenting the writing topic, (b) a section about generating and evaluating ideas, and (c) a section about selecting and organizing ideas into a writing plan. Both the content and organization sections required students to generate ideas individually followed by a collaborative discussion in which students shared their ideas and presented their writing plan. The second instrument was writing tests which were intended to measure students' writing skill in the form of paragraph of explanation texts. The analytical scoring rubric was employed to rate students' work in writing explanation texts. The scoring was concerned on five components, content, organization, grammar, vocabulary, and mechanics.

The students had been exposed by pre-writing activities previously to generate ideas for their paragraph; however, they worked individually in pre-writing activity. Thus, they were familiar to pre-writing activity before they were given the treatment of collaborative pre-writing discussion. In the first meeting, the class was divided into 2 groups in which each group consisted of 16 and 14 students. 16 students received a treatment which they had to work in groups (four students in each group) in collaborative pre-writing discussion. On the other hand, the rest of students (14 students) were treated to work in pairs. The structured prewriting worksheets were given to students. All students in each group initially brainstormed the ideas based on the given topic and they worked independently. Then, they shared those ideas, and how to organize them with their friend. These activities took about 30 minutes of class time. The topic that they had to discuss with their friends was an obstacle in learning Mathematics. As each group finished, 


\section{JEASP}

Journal of English for Academic and Specific Purposes

Volume 2 Number 2, December, 2019

students were assigned to write the explanation paragraph based on the outline from collaborative discussion worksheet. The second meeting, the group was shifted. It means that the group who worked in pair would work in small group to accomplish pre-writing activities and vice versa. Similar to previous meeting, they discussed to generate and evaluate their idea about how to learn math easier.

Students submitted two different paragraphs from two different treatment of collaborative pre-writing discussion. Copies of both paragraphs were made to be given to two raters in order for them to evaluate students writing quality. The data used in this study therefore comprised 60 explanation paragraphs. The two raters evaluated students writing which concerned on five components, content, organization, grammar, vocabulary, and mechanics. However, content and organization were given more weight $(35 \%)$ than other components because pre-writing activity that the students did emphasized on generating and evaluating the content and organization of the paragraph.

The students' drafts were evaluated by two EFL lecturers according to the marking criteria. Some activities were taken during the training process before they scored students writings. The activities are: (1) the raters were explained the purpose of the test, (2) the researcher explained the criteria for scoring the paragraph, (3) the raters practiced rating three paragraph samples of students' writing, and (4) the researcher correlated the scores of two raters to see whether the scorers were tolerable or not. Cronbach Alpha correlations were computed in order to compare the two raters' scores. The score from Cronbach Alpha was 0.97 which meant that the two raters were highly consistent when they rated the students' paragraph and so the inter-rater reliability was achieved.

Regarding to analyzing the data, there were two stages employed in the process of analyzing the data. The first was concerned with the descriptive statistics of which purpose was to reveal the characteristics of the data, like mean score. The second stage which dealt with the inferential statistics. In this stage, there were some steps that should be done by the researcher. The first was concerned with a test of fulfilment of statistical assumptions which consist of the tests of normality of the data to decide whether to use parametric or non-parametric test. The collected data from students writing was distributed normally so the researcher was required to use parametric test to test null hypothesis. Then, the second analysis was concerned with the hypothesis testing in 
order to answer the research problems. This statistical test aimed to investigate whether or not the difference was most probably due to the effect of independent variable of the study.

\section{FINDINGS}

This section presents the results of quantitative analyses conducted in relation to the question that prompted the study.

Table 1. Descriptive Statistics of Pair Work and Group Work

\begin{tabular}{|ll|l|l|l|l|}
\hline & Mean & N & Std. Deviation & Std. Error Mean \\
\hline Pair 1 & Pair_Work & 69.03 & 29 & 11.015 & 2.045 \\
& Group_Work & 74.45 & 29 & 9.489 & 1.762 \\
\hline
\end{tabular}

Table 1 shows that the descriptive statistics for students writing quality produced by pair work and group work. From table 1, it is revealed that the mean score for students' writing quality produced by groups (74.45) was higher than that produced by pairs (69.03). However, further analysis needed be conducted to decide whether the different mean was significant or not to determine whether or not the null hypothesis was rejected. Therefore, analyzing inferential statistic was conducted to test hypothesis to answer research problem on the number of participants in collaborative pre-writing discussion affect the students' writing quality.

Table 2. Paired Samples Test

\begin{tabular}{|c|c|c|c|c|c|c|c|c|}
\hline & Paired & Difference & & & & $\mathrm{t}$ & df & Sig. (2- \\
\hline & Mean & $\begin{array}{l}\text { Std. } \\
\text { Deviatio }\end{array}$ & $\begin{array}{l}\text { Std. } \\
\text { Error }\end{array}$ & $\begin{array}{l}95 \% \mathrm{C} \\
\text { the Diff }\end{array}$ & nce Interval of & & & \\
\hline & & & & Lower & Upper & & & \\
\hline $\begin{array}{ll}\text { Pair } 1 & \text { Pair_Work } \\
\text { Group_Work }\end{array}$ & $\begin{array}{l}- \\
5.41\end{array}$ & 14.384 & 2.671 & -10.885 & .058 & 2.027 & 28 & .052 \\
\hline
\end{tabular}




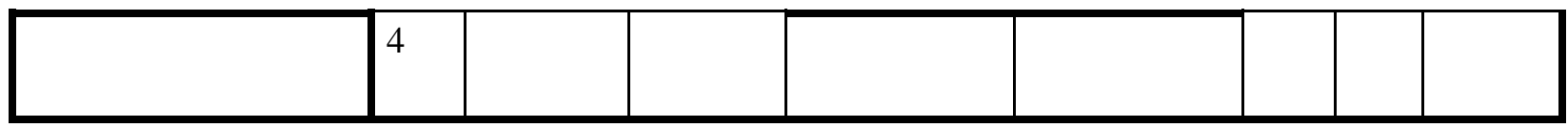

Paired $\mathrm{T}$ test was employed to ascertain whether there was any significant difference between pair work and small work. Table 2 shows that paired t test failed to reach the level of significance in which the Sig. value (P value) 0.052 was higher than the level of significance (0.052>0.05). The result of statistical computation, then, gave an empirical evidence to accept the null hypothesis. The acceptance of the null hypothesis meant the quality of written produced was not affected by the number of participants in collaborative pre-writing discussion.

\section{DISCUSSION}

This study revealed that the number of participants in collaborative pre-writing discussion did not have an effect on the quality of written produced by the student. Thus, two or more students could be assigned in collaborative pre-writing task to generate ideas, evaluate, and give feedback to other ideas.

Some factors might contribute the mean score of both treatments was not significant. First, both groups received the same treatment in which they collaborated to generate idea on a certain topic, evaluate other ideas and give feedback in pre-writing stage. Seow (2002) states that prewriting was one of writing stages in writing process to encourage students generate proper ideas to be used in drafting stage and to help them move away from having no ideas. Collaborative prewriting discussion in this study involved interaction in which it played an important role in building language knowledge by providing students with opportunities to share the knowledge with their friends and elicit help from other students (Neumann and McDonough, 2015). Therefore, the quality of written produced by students was not influenced by the number of participants in collaborative pre-writing discussion because both groups worked collaboratively to accomplish the same pre-writing activity.

Additional factor which might impact the findings was the characteristics of the task in pre-writing discussion. The task required both groups to select the idea individually followed by a collaborative discussion in which students shared their ideas and presented their writing plan. The task did not require the students to discuss language related problems such as grammar, vocabulary, and mechanic. The task encouraged discussion of organization which led students to 


\section{JEASP}

Journal of English for Academic and Specific Purposes

Volume 2 Number 2, December, 2019

discuss how to structure their written texts. As it was expected, the quality of written produced by the students related to grammar, vocabulary, and mechanics was influenced by the existing knowledge of every student and was not affected by the number of students. This finding was in line with what Funes (2015) and Ong \& Zhang (2010). The studies showed that task complexity in L2/FL writing as determined by familiarity of topic, genre, and/or task type, and reasoning demands seemed to have an impact on writing as a possible context for language learning. (Neumann and McDonough, 2015) revealed that the feature of collaborative pre-writing discussion worksheet focused on the content and organization. Meanwhile, the quality of students' writing in this study was not evaluated only by the quality of content and organization but also other aspects were evaluated too such as grammar, vocabulary, and mechanics. The quality of these elements tended to be influenced by individual competence as students wrote the paragraph individually after collaborating in pre-writing discussion. So, the quality of students' writing who worked in both pairs and groups were not affected by the numbers of participants during pre-writing activity.

Furthermore, the factor that could be contributed to insignificant difference between the pair and the small group was that students had limited time to discuss more detailed content of the given topic with their friends both in groups and in pairs. They probably only gave much attention to how to organize their idea in correct order. In addition, since they had to write the paragraph individually after discussion with their friends, plans might change while students were writing their paragraphs. The students might not necessarily incorporate their peers' feedback into their paragraphs, especially if they thought that their peers did not have good knowledge help them improve their writing, as (Neumann and McDonough, 2015) cautioned.

Another factor which might have contribute the result of the study was the amount of feedback that students needed in order to revise their writing draft and the students' ability to provide useful feedback to their peers. Some students might have the ability to provide valuable feedback about ideas and how to organize them into a good correct order. Other students might be good at giving suggestions on structure of sentences or the choice of words. The other students were good at mechanic's aspect such as spelling and punctuation. Also, some students might require more detailed feedback or in a different in order to truly benefit from and use it in their own writing.

Although discussion activity in planning stage of writing might facilitate meaningful interaction between/among the students who had different language proficiency, the degree of 
students' participation in the discussion would be varied. In this case, in small groups, especially when using discussion tasks where individual contributions were not obligatory for task completion, it is more likely perhaps that only the active and more confident students would talk to evaluate other ideas and gave feedback on the ideas. On the other hand, the passive student in the group would have not the courage to contribute to the discussion in groups, so the students might work individually. As a result, students who preferred individual work may not have been able to improve their paragraphs.

\section{CONCLUSION}

The current study provides evidence that the quality of students' writing is not influenced by the number of participants in collaborative pre-writing discussion as both of the groups gain insignificantly different score. Therefore, both pair and group work in collaborative pre-writing discussion should have their place in the EFL classroom.

Special attention should be given by teachers who apply collaborative pre-writing activities in term of students' learning style and attitude. Students who believe that collaborative prewriting discussion is useful may be in a position to exploit the learning opportunities it provides and benefit from it. However, if students do not see how collaborative discussion can improve their individual writing skills, they may be less inclined to participate actively both in pair and group work. It may be useful to provide students with a choice between pair and group prewriting activities. Fung (2010) states that the features that occur or emerge during collaborative writing reveal that students are capable of constructing knowledge and developing writing and social skills through interactions with their peers. However, affective conflict may sometimes hinder successful collaboration if not handled appropriately

Analyzing learners' roles and attitudes in collaborative interaction should be conducted during completing the pre-writing activities which focus on language-related episodes (LREs). It can give the researcher insight the nature of the oral interaction between the pairs and the groups as they collaborate throughout the pre-writing discussion. In addition, it can reveal the students who actively participate in generating, evaluating, and giving feedback to other ideas, or the students who are passively receive the ideas. 


\section{REFERENCES}

Al-Shaer, I. M. (2014). Employing Concept Mapping as Pre-Writing Strategy to Help EFL Learners Better Generate Argumentative Compositions. International Journal for the Scholarship of Teaching and Learning, 8(2)

Dobao, A. F (2012). Collaborative Writing Tasks in the L2 Classroom: Comparing Group, Pair, and Individual Work. Journal of Second Language Writing, 21, 40-58.

Dobao, A. F., \& Blum, A. (2013). Collaborative Writing in Pairs and Small Groups: Learners' Attitudes and Perception. System. 41, 365-378.

Ellis, R., \& Yuan, F. (2004). The Effects of Planning on Fluency, Complexity, and Accuracy in Second Language Narrative Writing. Studies in Second Language Acquisition, 26, 5984

Funes, M. R. (2015). Exploring the potential of second/foreign language writing for language learning: The effects of task factors and learner variables. Journal of Second Language Writing, 28, 1-19

Johnson, M. D \& Mercado, L \& Acevedo, A. (2012). The effect of planning sub-processes on L2 writing fluency, grammatical complexity, and lexical complexity. Journal of Second Language Writing 21, 264-282

Kucer, S. (2009). Dimensions of Literacy: A conceptual base for teaching reading and writing in school settings. (3rd Ed.). Mahwah, NJ: Erlbaum.

Lee, Y. (2013). Collaborative Concept Mapping as a Pre-Writing Strategy for L2 Learning: A Korean Application. International Journal of Information and Education Technology, $3(2)$

Lasito \& Storch, N (2013). Comparing Pair and Small Group Interactions on Oral Tasks. RELC Journal, 44(3), $361-375$

Mukminatien, N. (1997). The Differences of Students' Writing Achievements Across Different Course Levels. Unpublished Dissertation. Malang: State University of Malang

Neumann, H \& Mcdonough, K. (2015). Exploring Student Interaction during Collaborative Prewriting Discussions and its Relationship to L2 Writing. Journal of Second language Writing, 27, 84-104

Ong, J \& Zhang, L. J. (2010). Effects of Task Complexity on the Fluency and Lexical Complexity in EFL Students' Argumentative Writing. Journal of Second Language Writing, 19, 219-233

Peacock, M. (1999). A Useful and Popular Lesson? Comparing Students Working in Pairs and Threes in the ESL Classroom. RELC Journal, 29 (2)

Rao, Z (2007). Training in brainstorming and developing writing skills. ELTJ, 61 (2), 100-106

Richards, J. C \& Renandya, W. A. (2002). Methodology in Language Teaching. Cambridge: University Press. 
JEASP

Journal of English for Academic and Specific Purposes

Volume 2 Number 2, December, 2019

Seow, A. (2002). The writing process and process writing. Methodology in language teaching: An anthology of current practice, 315-320.

Servati, Ka (2012). Prewriting Strategies and their Effect on Student Writing. Education Masters. Paper 242.

Shi, L. (1998). Effects of prewriting discussions on adult ESL students' compositions. Journal of Second Language Writing, 7, 319-345

Swain, M., \& Lapkin, S. (1998). Interaction and second language learning: Two adolescent French immersion students working together. Modern Language Journal, 82, 320-337.

Widiati, U \& Cahyono, B.Y. (2006). The Teaching of EFL Writing in the Indonesian Context: The State of the Art. Journal Ilmu Pendidikan, 13 (3), 139-150. 